JIPSINDO No. 2, Volume 2, Maret 2015

\title{
UPAYA MENINGKATKAN HASIL BELAJAR IPS MELALUI MODEL PEMBELAJARAN DISCOVERY SISWA KELAS VIII F SMPN 2 NGEMPLAK TAHUN PELAJARAN 2014/2015
}

\author{
$\underline{\text { Titisari Handayani }}$ \\ SMPN 2 Ngemplak Sleman \\ Email : titisarih@yahoo.co.id, HP : 085868121414
}

\begin{abstract}
Abstrak
Penelitian ini bertujuan untuk meningkatkan hasil belajar IPS melalui model pembelajaran Discovery Siswa Kelas VIII F SMP N 2 Ngemplak Sleman Tahun Pelajaran 2014/2015. Penelitian ini merupakan penelitian tindakan kelas (PTK) yang mencakup perencanaan, pelaksanaan, observasi dan refleksi. Penelitian ini dilaksanakan dalam dua siklus. Subyek penelitian ini adalah siswa kelas VIIIF SMP Negeri 2 Ngemplak yang berjumlah 31 orang. Metode pengumpulan data menggunakan observasi, tes, catatan lapangan dan dokumentasi. Metode analisis data yang digunakan adalah metode deskriptif kuantitatif. Hasil penelitian sebagai berikut bahwa model pembelajaran discovery dapat meningkatkan hasil belajar IPS siswa kelas VIIIF SMP N 2 Ngemplak Sleman. Hal ini dibuktikan dari analisis hasil belajar siswa yang dilaksanakan menunjukkan adanya peningkatan. Pada prasiklus hasil rata-rata persentase ketuntasan belajar sebesar $35 \%$. Siklus I persentase ketuntasan belajar pada pre-tes $26 \%$ menjadi $68 \%$ pada post-tes dengan kategori kurang, jadi mengalami peningkatan $42 \%$. Pada siklus II persentase ketuntasan belajar dari 32\% pada pretes menjadi $90 \%$ pada postes dengan kategori baik sekali, jadi mengalami peningkatan sebesar 58\%. Hasil tersebut sudah sesuai dengan kriteria ketuntasan yang diharapkan bahkan melebihi target sebesar $75 \%$. Hal ini menunjukkan bahwa model pembelajaran discovery dapat meningkatkan hasil belajar.
\end{abstract}

Kata kunci : hasil belajar IPS, model pembelajaran discovery 


\begin{abstract}
This Research is aimed to Improve the IPS Learning Outcomes through discovery Learning Model in VIIIF class Of SMP N 2 Ngemplak Sleman Academic Year2014/2015. This Research is a classroom Action Research that includes planning, implementation, observation and reflection. Research lasted two cycles. Subject of this research is student of VIIIF class in SMPN 2 Ngemplak, all of them are 31 students. Methods of data collection use observation, evaluation, field notes and documentation. Data analysis method is descriptive quantitative methods. The results research can be summarized as follows: Discovery Learning Model can improve the Social learning outcomes student of VIIIF class in SMPN 2 Ngemplak Sleman.This is evident from the analysis of student learning outcomes conducted showed an increase, the average yield cycles completed learning percentage of $35 \%$, the first cycle of learning completeness percentage of $26 \%$ on the pretest to $68 \%$ on the posttest with less category, so an increase of $42 \%$. Second cycle learning completeness percentage of $32 \%$ on the pretest to $90 \%$ on the posttest with a very good category, so an increase of 58\%. These result are in accordance with the expected completeness criteria even exceeding the target of $75 \%$. It show that discovery learning model can improve learning outcomes.
\end{abstract}

Keywords : IPS learning outcomes, discovery learning model

\title{
Pendahuluan
}

Penyelenggaraan pendidikan nasional sesuai yang diamanatkan Undang-undang Sisdiknas adalah mengantarkan anak bangsa agar berkembang kemampuannya serta terbentuk watak atau karakter dan peradaban bangsa yang bermartabat. Harapan ke depan agar pendidikan nasional menghasilkan anak bangsa yang berkarakter dan cerdas akan senantiasa mengedepankan pertimbangan akal sehatnya dalam memutuskan segala sesuatu serta mampu mengendalikan emosinya. Untuk mencapai output pendidikan yang diharapkan tersebut diperlukan kegiatan belajar mengajar yang mengutamakan keseimbangan aspek kognitif, afektif dan psikomotorik. 
Proses pembelajaran terjadi secara internal pada diri peserta didik. Proses tersebut mungkin saja terjadi akibat dari stimulus luar yang diberikan guru, teman, lingkungan. Proses tersebut mungkin pula terjadi akibat dari stimulus dalam diri peserta didik yang terutama disebabkan oleh rasa ingin tahu. Proses pembelajaran dapat pula terjadi sebagai gabungan dari stimulus luar dan dalam. Dalam proses pembelajaran, guru perlu mengembangkan kedua stimulus pada diri setiap peserta didik (Lampiran IV Pedoman Umum Pembelajaran- Permendikbud No.81 A-4).

Kegiatan belajar pada era saat ini bukanlah belajar yang kaku dan mementingkan materi pelajaran. Dunia pendidikan sekarang adalah tempat dimana orang harus mengerahkan seluruh kekuatan, pikiran, dan kemampuan yang memerlukan kreativitas tinggi. Pembelajaran yang diperlukan saat ini adalah pembelajaran yang luwes, penuh kegembiraan, bekerjasama, mementingkan aktivitas, dan kontekstual. Kegiatan belajar sebagai kegiatan yang penting selama hidup manusia, menjadi pengalaman yang menyenangkan, merangsang pikiran dan mengembangkan penalaran siswa. Berbagai cara dapat ditempuh oleh guru agar pembelajaran menarik dan kontekstual, tidak membosankan, mudah dipahami dan mudah dimengerti sehingga pembelajaran tidak mudah dilupakan. Setiap pendidik bertanggung jawab terhadap mutu kegiatan pembelajaran untuk setiap program pembelajaran yang diampunya, dengan mengacu pada kurikulum yang berlaku, diantaranya menerapkan kurikulum 2013 yang bercirikan menggunakan pendekatan Saintifik. Langkah-langkah Saintifik dikenal dengan $5 \mathrm{M}$ yaitu Mengamati, Menanya, Mencari Informasi, Mengasosiasi dan Mengomunikasikan. (Materi Pelatihan Guru Implementasi Kurikulum 2013). Kegiatan Pembelajaran 
dengan pendekatan Saintifik dapat dilaksanakan dengan metode pembelajaran kooperatif dan model pembelajaran diantaranya model pembelajaran discovery.

Model pembelajaran discovery adalah model mengajar yang mengatur pengajaran sedemikian rupa sehingga anak memperoleh pengetahuan yang sebelumnya belum diketahuinya itu tidak melalui pemberitahuan, sebagian atau seluruhnya ditemukan sendiri (Sulipan, 2011: 1). Adapun langkah-langkah pembelajaran model discovery adalah stimulation, problem statement, data collection, data processing dan verification.

Kegiatan belajar mengajar yang dilakukan di SMP Negeri 2 Ngemplak Kabupaten Sleman pada umumnya menggunakan metode ceramah. Penerapan metode ceramah dapat menimbulkan kejenuhan pada siswa, kurang merangsang partisipasi siswa sehingga proses belajar terjadi hanya satu arah. Akibatnya,pembelajaran pun kurang menarik, tidak menyenangkan, dan membuat jenuh bagi siswa. Siswa hanya menjadi penerima pasif, kurang responsif, dan ada kecenderungan untuk menolak berinteraksi dengan guru. Kondisi tersebut berpengaruh pada hasil belajar, sebagai bukti dari hasil ulangan yang dilakukan sebelumnya di kelas VIIIF kurang memuaskan, dari 31 siswa yang mendapatkan hasil sesuai dan di atas kriteria ketuntasan minimal $(\mathrm{KKM}=75)$ hanya 11 siswa sedangkan 20 siswa di bawah KKM. Secara klasikal ketuntasan belajar hanya $35 \%$ dari yang ditetapkan sebesar 85\%, belum sesuai yang diharapkan.

Dari permasalahan yang ada di kelas VIII F SMPN 2 Ngemplak dalam proses pembelajaran IPS, maka guru berusaha untuk mengatasi hasil belajar siswa yang rendah tersebut dengan menggunakan model pembelajaran discovery. Adapun masalah 
dirumuskan sebagai berikut : Bagaimanakah meningkatkan hasil belajar IPS melalui model pembelajaran discovery siswa kelas VIII F SMPN 2 Ngemplak Sleman tahun pelajaran 2014/2015? Berdasarkan rumusan masalah yang ditetapkan maka tujuan penelitian ini untuk mengetahui peningkatan hasil belajar IPS melalui model pembelajaran Discovery siswa kelas VIIIF SMPN 2 Ngemplak tahun pelajaran 2014/2015.

\section{Hasil belajar}

Langkah terakhir dari proses pembelajaran adalah melaksanakan evaluasi atau penilaian terhadap sejauh mana proses pembelajaran dapat mencapai tujuan. Evaluasi atau penilaian merupakan salah satu komponen system pembelajaran. Pengembangan alat evaluasi merupakan bagian integral dalam pengembangan system pembelajaran. Oleh karena fungsi evaluasi adalah untuk mengetahui apakah tujuan yang dirumuskan dapat tercapai, evaluasi merupakan salah satu factor penting dalam proses pembelajaran (Sumiati dan Asra, 2009:200). Pendapat tersebut diperkuat Sunarti dan Selly (2012:1) yang mengemukakan bahwa penilaian merupakan rangkaian kegiatan untuk memperoleh, menganalisis dan menafsirkan data btentang proses dan hasil belajar peserta didik yang dilakukan secara sistematis dan berkesinambungan, sehingga menjadi informasi yang bermakna dalam mengambil keputusan.

Hasil belajar yang diperoleh dari penilaian dinyatakan dalam bentuk hasil belajar. Oleh sebab itu tindakan atau kegiatan tersebut dinamakan penilaian hasil belajar (Nana Sudjana,2013:111). Hasil belajar merupakan kemampuankemampuan yang dimiliki siswa setelah ia menerima pengalaman belajarnya. Untuk itu jika seorang pendidik merasa bertanggung 
jawab atas penyempurnaan pendidikannya, ia harus mengevaluasi pendidikannya itu agar mengetahui perubahan apa yang harus dilakukan. Seorang pendidik perlu untuk mengevaluasi penyempurnaan pendidikannya dan peserta didiknya. Hal senada disampaikan oleh Dimyati \& Mujiono (2006:3) bahwa hasil belajar merupakan hasil dari suatu interaksi tindak belajar dan tindak mengajar. Dari sisi guru, tindak mengajar diakhiri dengan proses evaluasi hasil belajar. Dari sisi siswa, hasil belajar merupakan berakhirnya penggal dan puncak proses belajar. Lebih lanjut Nana Syaodih (2003:102) menyatakan bahwa hasil belajar atau achievement merupakan realisasi atau pemekaran dari kecakapankecakapan potensial atau kapasitas yang dimiliki seseorang.

Menurut Gagne, belajar merupakan kegiatan yang kompleks, dan hasil belajar berupa kapabilitas. Setelah belajar, seseorang akan memiliki keterampilan, pengetahuan, sikap dan nilai. Belajar diklasifikasikan dalam tiga komponen penting, yaitu: kondisi eksternal, kondisi internal dan hasil belajar. Belajar merupakan interaksi antara keadaan internal dan proses kognitif siswa dengan stimulus dari lingkungan. Proses kognitif tersebu menghasilkan suatu hasil belajar. Hasil belajar tersebut terdiri dari informasi verbal, keterampilan intelek, keterapilan motorik, sikap dan siasat politik (Dimyati, 2013: 11 )

Adapun kegunaan hasil belajar atau penilaian tersebut menurut Sunarti dan Selly (2012:2) antara lain sebagai umpan balik bagi siswa dalam mengetahui kemampuan dan kekurangannya sehingga menimbulkan motivasi untuk memperbaiki hasil belajarnya; memberikan masukan bagi guru untuk memperbaiki program pembelajarannya di kelas. 


\section{Model Pembelajaran Discovery}

Model pembelajaran Discovery adalah model mengajar yang mengatur pengajaran sedemikian rupa sehingga anak memperoleh pengetahuan yang sebelumnya belum diketahuinya itu tidak melalui pemberitahuan, sebagian atau seluruhnya ditemukan sendiri (Sulipan, 2011: 1). Model Discovery memiliki beberapa keunggulan antara lain : siswa aktif dalam kegiatan belajar, sebab ia berpikir dan menggunakan kemampuan untuk menemukan hasil akhir; siswa memahami benar bahan pelajaran, sebab mengalami sendiri proses menemukannya. Sesuatu yang diperoleh dengan cara ini lebih lama diingat; menemukan sendiri menimbulkan rasa puas. Kepuasan batin ini mendorong ingin melakukan penemuan lagi sehingga minat belajarnya meningkat; dan siswa yang memperoleh pengetahuan dengan metode penemuan akan lebih mampu mentransfer pengetahuannya ke berbagai konteks (Suherman, 2001: 179).

Pendapat Masarudin Siregar dalam Mohammad Takdir Illahi (2012:30) tentang pembelajaran Discovery adalah proses pembelajaran untuk menemukan sesuatu yang baru dalam kegiatan belajar mengajar. Proses belajar dapat menemukan sesuatu apabila pendidik menyusun terlebih dahulu beragam materi yang akan disampaikan, selanjutnya mereka dapat melakukan proses untuk menemukan sendiri berbagai hal penting terkait dengan kesulitan dalam pembelajaran. Menurut Sulipan, (2011: 1), metode/model pembelajaran discovery (penemuan) adalah metode mengajar yang mengatur pengajaran sedemikian rupa sehingga anak memperoleh pengetahuan yang sebelumnya belum diketahuinya itu tidak melalui pemberitahuan, sebagian atau seluruhnya ditemukan sendiri. Dalam pembelajaran discovery, kegiatan atau pembelajaran yang dirancang sedemikian 
rupa sehingga siswa dapat menemukan konsep-konsep dan prinsip-prinsip melalui proses mentalnya sendiri. Dalam menemukan konsep, siswa melakukan pengamatan, menggolongkan, membuat dugaan, menjelaskan, menarik kesimpulan dan sebagainya untuk menemukan beberapa konsep atau prinsip.

Syah dalam Yunus Abidin (2014:177) mengatakan bahwa tahapan atau langkah-langkah pembelajaran discovery adalah sebagai berikut:

a. Stimulasi

Pada tahap ini siswa dihadapkan pada sesuatu yang menimbulkan kebingungan dan dirangsang untuk melakukan kegiatan penyelidikan guna menjawab kebingungan tesebut. Kebingungan dalam diri siswa ini sejalan dengan adanya informasi yang belum tuntas disajikan guru.

b. Menyatakan masalah

Pada tahap ini siswa diarahkan untuk mengidentifikasi sebanyak mungkin masalah yang relevan dengan bahan pelajaran, kemudian salah satunya dipilih dan dirumuskan dalam bentuk hipotesis.

c. Pengumpulan data

Pada tahap ini siswa ditugaskan untuk melakukan kegiatan eksplorasi, pencarian, dan penelusuran dalam rangka mengumpulkan informasi sebanyak-banyaknya yang relevan untuk membuktikan benar hipotesis yang telah diajukannya. Kegiatan ini dapat dilakukan melalui aktivitas wawancara, kunjungan lapangan dan atau kunjungan pustaka. 
d. Pengolahan data

Pada tahap ini siswa mengolah data dan informasi yang telah diperolehnya baik melalui wawancara, observasi dan sebagainya.

e. Pembuktian

Pada tahap ini siswa melakukan pemeriksaan secara cermat untuk membuktikan benar atau tidaknya hipotesis yang ditetapkan tadi dengan temuan alternatif, dihubungkan dengan hasil pengolahan data.

f. Menarik kesimpulan

Pada tahap ini siswa menarik sebuah kesimpulan yang dapat dijadikan prinsip umum dan berlaku untuk semua kejadian atau masalah yang sama, dengan memperhatikan verifikasi.

Beberapa keunggulan model Discovery diungkapkan oleh Suherman, dkk (2001: 179) sebagai berikut:

a. siswa aktif dalam kegiatan belajar, sebab ia berpikir dan menggunakan kemampuan untuk menemukan hasil akhir;

b. siswa memahami benar bahan pelajaran, sebab mengalami sendiri proses menemukannya. Sesuatu yang diperoleh dengan cara ini lebih lama diingat;

c. menemukan sendiri menimbulkan rasa puas. Kepuasan batin ini mendorong ingin melakukan penemuan lagi sehingga minat belajarnya meningkat;

d. siswa yang memperoleh pengetahuan dengan metode penemuan akan lebih mampu mentransfer pengetahuannya ke berbagai konteks;

e. metode ini melatih siswa untuk lebih banyak belajar sendiri.

Adapun kelemahan model discovery menurut Mohammad Takdir Illahi (2012: 72 - 73) ada beberapa yaitu : 
a. Berkenaan dengan waktu. Belajar mengajar menggunakan model discovery membutuhkan waktu yang lebih lama dibandingkan dengan metode langsung. Pembelajaran model ini membutuhkan tahapan-tahapan yang panjang dan kemampuan memanfaatkan waktu dengan sebaik-baiknya.

b. Bagi anak didik yang berusia muda, kemampuan berpikir rasional mereka masih terbatas. Mereka sering menggunakan empirisnya yang sangat subjektif untuk memperkuat pelaksanaan prakonsepnya.

c. Faktor kebudayaan dan kebiasaan. Belajar menggunakan model discovery dituntut kemandirian, kepercayaan kepada dirinya sendiri, dan kebiasaan bertindak sebagai subjek.

\section{Metode Penelitian}

Penelitian tindakan kelas dilaksanakan di SMPN 2 Ngemplak, Sleman, D I Yogyakarta, Penelitian ini dilaksanakan pada semester genap tahun pelajaran 2014/2015. Waktu penelitian enam bulan mulai dari penulisan proposal, pengamatan kondisi awal, tindakan sampai penulisan laporan. Pelaksanaan penelitian direncanakan dua siklus dengan tiga kali pertemuan tetapi tidak menutup kemungkinan bertambah siklusnya apabila hasilnya belum sesuai dengan yang diharapkan. Subjek penelitian ini adalah siswa kelas VIIIF di SMPN 2 Ngemplak kabupaten Sleman yang berjumlah 31 siswa terdiri dari 14 siswa laki-lai dan 17 siswa perempuan. Pemilihan subjek kelas VIIIF ini karena siswa kelas tersebut memiliki permasalahan dalam hasil belajar mata pelajaran IPS. Berdasarkan hasil ulangan yang dilakukan sebelumnya menunjukkan persentase siswa yang belum tuntas 65\%. Dari KKM yang telah ditentukan (KKM : 75). 
Penelitian ini menggunakan rancangan penelitian tindakan kelas (PTK) dengan acuan model siklus PTK yang dikembangkan oleh Kemmis dan Taggart yang terdiri dari perencanaan, tindakan, pengamatan dan refleksi. Penelitian dimulai dari pengamatan awal terhadap proses pembelajaran IPS kelas VIIIF. Selanjutnya peneliti merancang pemecahan masalah dengan menggunakan model pembelajaran discovery. Penelitian ini dirancang menjadi beberapa siklus dengan tiap siklusnya terdiri dari tiga kali tatap muka, dengan alokasi waktu 3×40 menit. Penelitian dihentikan jika hasil yang dicapai telah sesuai dengan target keberhasilan yang telah ditetapkan. Pengumpulan data dalam penelitian ini menggunakan beberapa metode yaitu observasi, angket, tes, dokumentasi dan catatan lapangan.

Metode analisis data yang digunakan dalam penelitian ini adalah analisis deskriptif kuantitatif. Untuk validasi data, dalam penelitian ini digunakan metode Triangulasi dengan memanfaatkan berbagai sumber dan metode Expert yaitu alat ukur atau instrument yang akan diujicobakan kepada responden, terlebih dahulu dikonsultasikan kepada para ahli.

\section{Hasil Penelitian}

Hasil penelitian awal (prasiklus) hasil belajar siswa, peneliti melakukan pengamatan hasil Ulangan Harian diketahui terdapat $35 \%$ nilai hasil belajar yang tuntas dan $65 \%$ yang tidak tuntas. Adapun nilai tertinggi 81 dan nilai terendah 47, sedangkan nilai rata-rata kelas 69, sehingga secara klasikal baik dari rata-rata kelas maupun persentase jumlah siswa sebelum dilakukan tindakan kelas masih jauh dari KKM $(\mathrm{KKM}=75)$.

Mengingat permasalahan yang dihadapi seperti digambarkan pada penelitian awal di atas, maka perlu adanya upaya 
meningkatkan hasil belajar siswa dalam pembelajaran IPS. Untuk mengatasinya dilakukan tindakan dengan menggunakan model pembelajaran discovery.

a. Hasil Siklus I

Siklus I dilaksanakan dengan tiga kali pertemuan yaitu pada tanggal 23 Februari, 24 Februari dan 2 Maret 2015 dimana satu pertemuannya dua jam pelajaran atau 2 x 40 menit dengan Kompetensi Dasar yaitu 7.1 Mendeskripsikan permasalahan angkatan kerja dan tenaga kerja sebagai sumber daya dalam kegiatan ekonomi, serta peran pemerintah dalam upaya penanggulangannya.

Hasil belajar siswa pada siklus I, diketahui bahwa berdasarkan Kriteria Ketuntasan Minimal (KKM = 75) maka siswa yang sudah tuntas atau nilai diatas KKM pada saat pretes adalah $26 \%$, kemudian pada saat postes meningkat menjadi sebesar 68 $\%$ masih termasuk kategori kurang, namun mengalami peningkatan sebesar $42 \%$. Ketuntasan siswa secara klasikal masih jauh di bawah target keberhasilan penelitian yang ditargetkan. Untuk nilai rata-rata pada pretes sebesar 67 dengan nilai tertinggi sebesar 78 dan terendah 45, sedangkan setelah dilakukan tindakan dengan model pembelajaran Discovery, pada postes mengalami peningkatan yaitu nilai rata-rata 74 dengan nilai tertinggi 85 dan terendah 60. Pada saat kegiatan pembelajaran siklus I, berdasarkan hasil observasi dan catatan lapangan, terdapat beberapa kendala yang dapat direfleksi sebagai berikut :

1). Siswa belum pernah melaksanakan kegiatan pembelajaran dengan model Discovery, jadi pada pertemuan pertama masih ada beberapa siswa yang kebingungan akan apa yang harus dilakukan meskipun sudah ada LKS ( Lembar Kegiatan Siswa) 
2). Beberapa kelompok masih kebingungan dalam melaksanakan langkah pembelajaran discovery yang kedua yaitu menentukan permasalahan meskipun sudah dibimbing.

3). Waktu untuk presentasi kurang sehingga digunakan cara dengan menempelkan hasil kerja kelompok di kertas manila dan ditempelkan di dinding. Kemudian tiap dua kelompok berpasangan saling mengamati dan mengkomunikasikan secara klasikal bila ditemukan hal-hal yang berbeda.

4). Saat mengemukakan hasil yang berbeda, masih ada kelompok yang enggan menyampaikan temuannya.

5). Hasil belajar secara klasikal untuk siswa yang sudah tuntas atau mencapai nilai di atas KKM pada saat pretes presentase nilainya sebesar $26 \%$, kemudian pada saat postes sebesar 68 $\%$, termasuk kategori kurang, namun mengalami peningkatan sebesar $42 \%$.

Hasil refleksi tersebut di atas digunakan untuk memperbaiki dan dilaksanakan pada siklus II.

b. Hasil Siklus II

Siklus II dilaksanakan pada tanggal 9, 10 dan 16 Maret 2015 dengan tiga kali pertemuan dimana satu pertemuannya $2 \mathrm{x}$ 40 menit. Siklus II merupakan perbaikan dari siklus I, yang dilaksanakan dengan judul materi“Pajak Dalam Perekonomian Nasional“.

Hasil belajar pada siklus II secara klasikal untuk siswa yang sudah tuntas atau nilai diatas KKM pada saat pretes adalah $32 \%$, kemudian pada saat postes sebesar $90 \%$ termasuk kategori baik sekali. Pada saat siklus II persentase ketuntasan hasil belajar mengalami peningkatan sebesar $58 \%$. Ketuntasan siswa secara klasikal sudah melampui target keberhasilan penelitian yang ditargetkan sebesar $75 \%$. Untuk nilai rata-rata pada pretes 
sebesar 65 dengan nilai tertinggi sebesar 85 dan terendah 50, sedangkan setelah dilakukan tindakan dengan model pembelajaran Discovery, pada saat postes nilai rata-rata 88 dengan nilai tertinggi 95 dan terendah 70 .

c. Analisis Hasil Belajar Siswa

Dalam menganalisis hasil belajar peneliti akan mencoba melihat dari presentase ketuntasan dan perolehan nilai yang tertinggi dan terendah. Hal ini untuk memberikan gambaran adanya peningkatan hasil belajar melalui Metode discovery dalam proses pembelajaran. Analisis tingkat persentase ketuntasan dalam proses pembelajaran mulai dari prasiklus, siklus I dan siklus II disajikan dalam tabel sebagai berikut:

Tabel 1. Analisis Persentase Ketuntasan Hasil Belajar Siswa

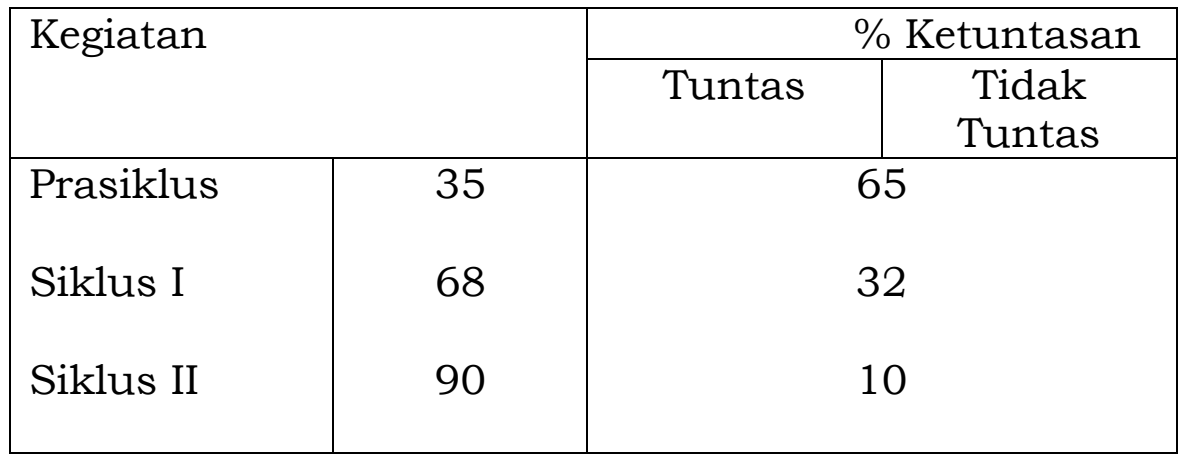

Sumber: Analisis hasil belajar siswa

Lebih jelasnya digambarkan dengan diagram sebagai berikut: 
JIPSINDO No. 2, Volume 2, Maret 2015

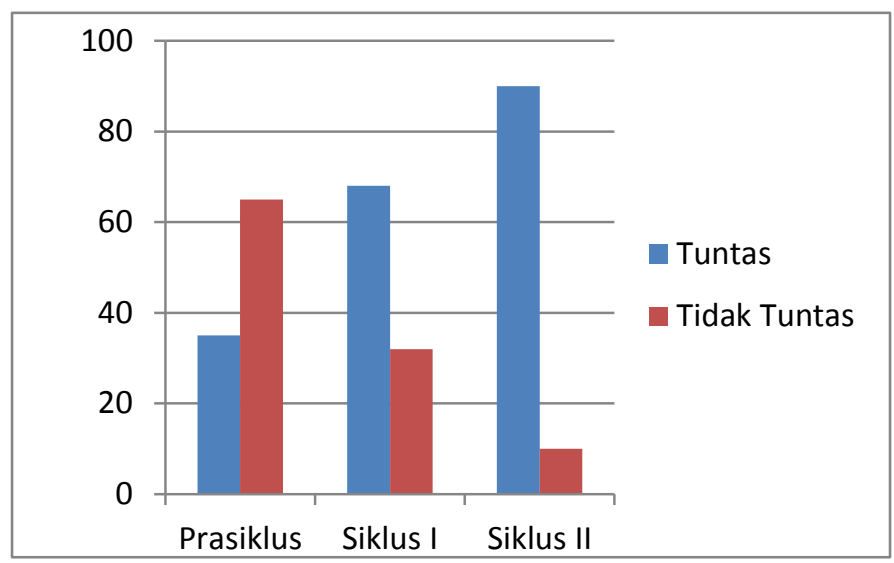

Gambar 1. Prosentase ketuntasan hasil belajar siswa

Dilihat dari presentase ketuntasan sebelum perlakuan dan setelah perlakuan Pada siklus I sebelum perlakuan (pretes) 32\% setelah perlakuan (postes) 68\% mengalami peningkatan sebesar 36\%. Hal ini menggambarkan adanya pengaruh metode Discovery sebesar 36\% pada siklus pertama namun belum mencapai batas KKM. Sedangkan pada siklus II presentase ketuntasan sebelum perlakuan (pretes) 32\% setelah perlakuan (postes) 90\% mengalami peningkatan sebesar $58 \%$. Pengaruh Metode Discovery pada siklus II dengan materi yang lain mampu meningkatkan presentase ketuntasan sebesar $58 \%$ dan presentase ketuntasan menjadi 90\% melebihi batas KKM yaitu 75\%, artinya pada siklus II sudah berhasil melebihi target yang ditentukan, lebih jelasnya dapat dilihat pada gambar berikut:

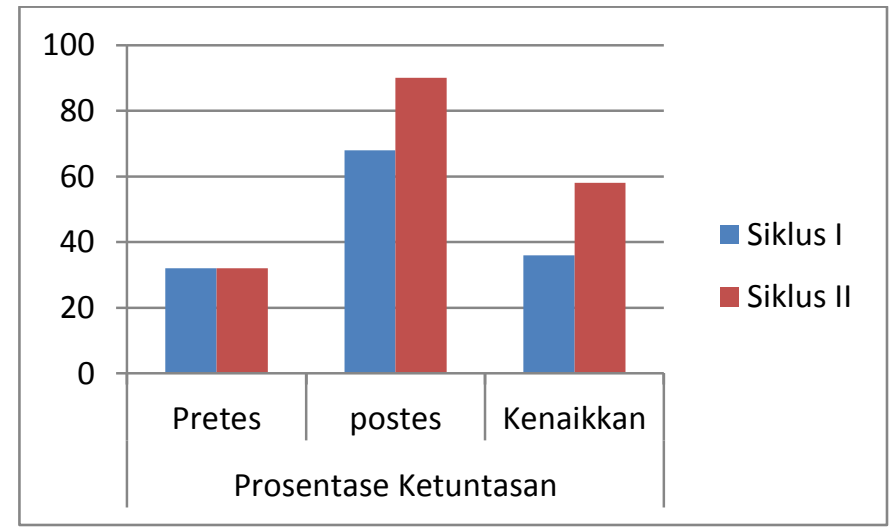

Gambar 2. Prosentase kenaikkan ketuntasan hasil belajar siswa 
Analisis hasil belajar dilihat dari parameter rata-rata kelas, hasil tertinggi dan terendah dalam proses pembelajaran mulai dari prasiklus, siklus I dan siklus II disajikan dalam tabel sebagai berikut:

Tabel 2

Analisis Persentase Nilai Hasil Belajar Siswa Tertinggi dan Terendah

\begin{tabular}{|l|r|r|r|}
\hline Kegiatan & \multicolumn{3}{|c|}{ Nilai Hasil Belajar } \\
\cline { 2 - 4 } & $\begin{array}{c}\text { Rata-rata } \\
\text { kelas }\end{array}$ & Tertinggi & Terendah \\
\hline Prasiklus & 69 & 81 & 47 \\
Siklus I & 74 & 85 & 60 \\
Siklus II & 88 & 95 & 70 \\
\hline
\end{tabular}

Sumber: nilai hasil belajar siswa tertinggi dan terendah

Lebih jelasnya analisis hasil belajar siswa dengan parameter nilai rata-rata kelas, tertinggi dan terendah digambarkan dengan diagram sebagai berikut:

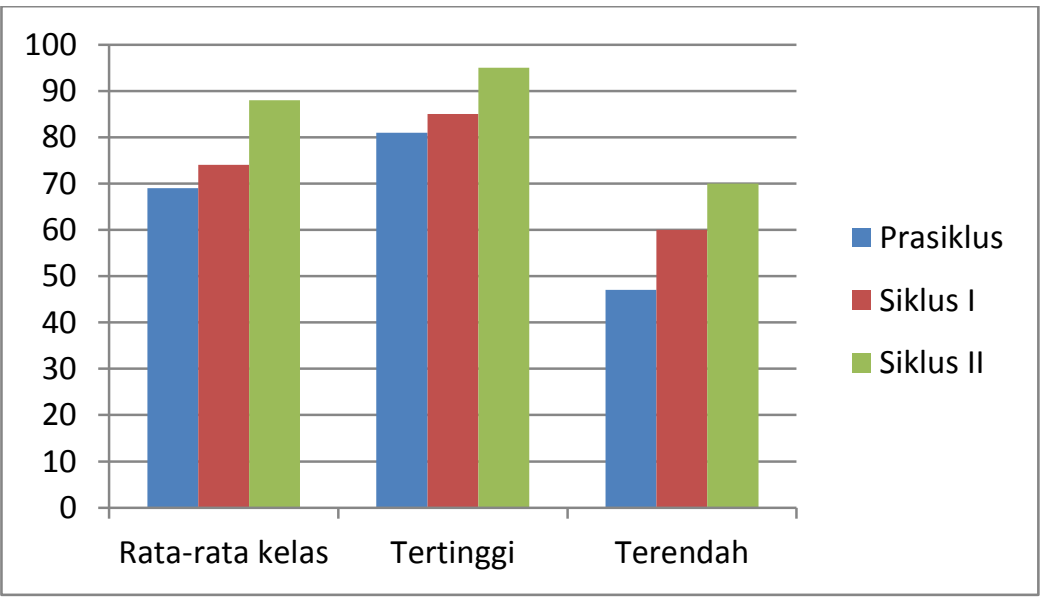

Gambar 3. Analisis hasil belajar siswa dengan parameter nilai rata-rata kelas, tertinggi dan terendah 


\section{Simpulan}

Berdasarkan analisis hasil penelitian yang telah dilakukan, dapat ditarik kesimpulan sebagai berikut model pembelajaran discovery dapat meningkatkan hasil belajar siswa, hal ini dapat dilihat pada analisis hasil tes, pada prasiklus presentase nilai dibawah $\mathrm{KKM}=65 \%$ dan presentase nilai yang tuntas $\mathrm{KKM}$ sebesar 35\%. Pada siklus I hasil tes meningkat, presentase nilai pretes yang tuntas KKM sebesar 26\% dan presentase nilai postes yang tuntas KKM sebesar 68\% dengan kategori kurang, meskipun mengalami peningkatan 42\%. Pada siklus II meningkat lagi dengan presentase nilai pretes yang tuntas KKM sebesar 32\% dan presentase nilai postes yang tuntas KKM sebesar 90\% dengan kategori sangat baik. Jadi mengalami peningkatan 58\%. Ketuntasan kelas sudah terlampaui karena targetnya 75 \% dengan kriteria baik.

\section{Saran}

1. Guru sebaiknya mencoba berbagai model / metode dalam proses pembelajaran contohnya model discovery untuk meningkatkan hasil belajar siswa.

2. Guru harus kreatif dan inovatif dalam mengajar agar siswa tidak bosan dan pembelajaran menjadi menyenangkan.

3. Guru harus dapat memanfaatkan sumber-sumber belajar yang ada di sekolah maupun lingkungan sekitar.

\section{Daftar Pustaka}

Acep Yoni S.S.dkk. (2010). Menyusun Penelitian Tindakan Kelas. Yogyakarta: Familia.

Depdiknas. (2006). Kurikulum 2006 Mata Pelajaran Ilmu Pengetahuan Sosial Untuk Sekolah Menengah Pertama 
(SMP)/Madrasah Tsanawiyah (MTs). Jakarta: Direktorat Pendidikan.

Husaini Usman \& Purnomo S.A. (2006). Metodologi Penelitian Sosial. Jakarta: Bumu Aksara.

Nana Syaodih S. (2003). Landasan Psikologi Proses Pendidikan. Bandung: Rosda karya.

Nana Sudjana. (2013). Dasar-dasar Proses Belajar Mengajar. Bandung: Sinar Baru Algensindo.

Oemar Hamalik Prof. Dr. (2009). Pendekatan Baru, Strategi Belajar Mengajar Berdasarkan CBSA. Bandung: Sinar Baru Algensindo.

Kemdikbud. (2014). Buku Guru Ilmu Pengetahuan Sosial kelas VIII. Jakarta: Kementrian pendidikan dan Kebudayaan.

Pardjono dkk. (2007). Panduan Penelitian Tindakan Kelas. Yogyakarta: Lembaga Penelitian UNY.

Ratno Harsanto. (2007). Pengelolaan Kelas Yang Dinamis Paradigma Baru Pembelajaran Menuju Kompetensi Siswa cetakan V Yogyakarta Kanisius.

Sri Rumini. (1997). Psikologi Pendidikan. Yogyakarta : Unit Percetakan dan Penerbitan Universitas Negeri Yogyakarta.

Sugiyanto. (2010). Model-model Pembelajaran Inovatif. Surakarta: Yuma Pustaka.

Suharsimi, A. (2001). Dasar-dasar Evaluasi Pendidikan. Jakarta : Rineka Cipta.

Supardi. (2011). Dasar-dasar Ilmu Sosial. Yogyakarta: Ombak.

Sunarti \& Selly R (2012). Penilaian Hasil Belajar Untuk SD, SMP dan SMA. Yogyakarta : Andi Office.

Takdir Illahi, Mohammad. (2012). Pembelajaran Discovery Strategy \& Mental Vocational Skill. Yogyakarta: Diva Press. 